ТЕОРЕТИЧНІ ТА ПРАКТИЧНІ ЗАСАДИ ФОРМУВАННЯ ІНФОРМАЦІЙНО-ЦИФРОВОЇ КУЛЬТУРИ МАЙБУТНІХ ФАХІВЦІВ ФІЗИЧНОЇ КУЛЬТУРИ І СПОРТУ В УМОВАХ ЗМІШАНОГО НАВЧАННЯ

\author{
THEORETICAL AND PRACTICAL PRINCIPLES OF FORMATION \\ OF INFORMATION AND DIGITAL CULTURE OF FUTURE SPECIALISTS \\ OF PHYSICAL CULTURE AND SPORTS IN THE CONDITIONS \\ OF BLENDED LEARNING
}

УДК 378:[37.091.12.011.3-051:796] DOI https://doi.org/10.32843/26636085/2020/29-1.32

\footnotetext{
Лазоренко С.А.,

канд. наук з фрізичного виховання

і спорту, доцент,

завідувач кафедри спортивних

дисциплін і фрізичного виховання

Сумського державного педагогічного

університету імені А.С. Макаренка
}

\begin{abstract}
Стаття присвячена одній із актуальних проблем професійної підготовки майбутніх фрахівців фрізичної культури та спорту - розвитку їхньої інсрормаційно-цифррової культури в умовах змішаного навчання. Формування інфрормаційно-цифррової культури майбутніх фрахівців фрізичної культури та спорту в умовах змішаного навчання ми описуємо як цілісну структуру, що забезпечуватиме системну професійну підготовку майбутніх фрахівців ФКіС. У основу процесу формування інфрормаційно-цифррової культури майбутніх фрахівців фрізичної культури та спорту в умовах змішаного навчання ми поклали методологічні підходи й принципи. Теоретичний концепт визначає систему ідей, вихідних категорій, основних понять. Практичний концепт описує систему дій, які забезпечують практичне розв'язання поставленої проблеми. Відповідно, прочес формування інформаційно-цифрової культури майбутніх фрахівців ФКіС в умовах змішаного навчання передбачає вдосконалення змісту, методів і засобів навчання та форм навчальної діяльності студентів. Модель фрормування інформаційно-цифрової культури майбутніх фрахівців ФКіС в умовах змішаного навчання включає діагностику результатів професійної підготовки, яка базується на критеріях і показниках сорормованості складових інформаційно-цифррової культури майбутніх фрахівців ФКіС. Результатом реалізації моделі є позитивна динаміка в рівнях сорормованості складників інфрормаційно-цифррової культури майбутніх фрахівців ФКіС. У процесі фрормування інфоомаційно-цифрової культури майбутніх фахівців ФКіС варто активно використовувати IT, що серед іншого передбачає розробку й використання освітніх ресурсів, дає можливість студентам відчути себе суб'єктом освітнього процесу, побачити переваги використання IT у професійній діяльності й визначити власні шляхи саморозвитку в профресійному напрямку.

Ключові слова: професійна підготовка, майбутні фрахівиі фрізичної культури та спорту, інформаційно-цифррова культура, змішане навчання.
\end{abstract}

The article is devoted to one of the current problems of professional training of future specialists in physical culture and sports - the development of their information and digital culture in a blended learning environment. We describe the formation of information and digital culture of future specialists in physical culture and sports in the conditions of blended learning as a holistic structure that will provide systematic professional training of future specialists of FCiS. We based our methodological approaches and principles on the process of forming the information and digital culture of future specialists in physical culture and sports in the conditions of blended learning. The theoretical concept defines a system of ideas, source categories, basic concepts. The practical concept describes a system of actions that provide a practical solution to the problem. Accordingly, the process of formation of information and digital culture of future specialists of FCiS in the conditions of blended learning involves the improvement of the content, methods and means of teaching and forms of educational activities of students. The model of formation of information and digital culture of future specialists of FKiS in the conditions of mixed training includes diagnostics of results of professional training which is based on criteria and indicators of formation of components of information and digital culture of future specialists of FKiS. The result of the model implementation is a positive dynamics in the levels of formation of the components of information and digital culture of future specialists FKiS. In the process of forming the information and digital culture of future specialists FKiS should actively use IT, which, among other things, involves the development and use of educational resources, allows students to feel the subject of the educational process, see the benefits of using IT in professional activities and identify their own ways of professional development. direction.

Key words: professional training; future specialists in physical culture and sports; information and digital culture; blended learning.
Постановка проблеми в загальному вигляді. Домінуючий вектор розвитку сучасної освіти $є$ ії технологізація, під якою розуміють організацію освітньої діяльності, методи, форми діяльності учнів і педагогів і діагностику навчальних досягнень. Сучасне суспільство переживає історичний етап свого розвитку, який характеризується переходом від індустріальної до інформаційної епохи, що відображено в стрімкому розвитку інформа- ційно-комунікаційних технологій і їх упровадженні в усі сфери життєдіяльності суспільства, зокрема інформатизації освіти.

Сучасна система освітнього процесу не може залишитися осторонь глобального процесу інформатизації суспільства. Ії̈ значення останнім часом зростає і якісно впливає на процес формування та розвитку інформаційно-цифррової культури майбутніх фрахівців ФКіС. 
Аналіз останніх досліджень і публікацій. Загальна тенденція розвитку системи освіти майбутніх фахівців із фрізичної культури ґрунтується на аксіологічному, компетентнісному й технологічному підходах до організації освітнього процесу (Л. Пєвіцина, Ж. Бережна) й передбачає формування їхньої здоров'язбережувальної компетенції (Н. Завидівська, В. Зданюк, О. Іщук), готовності до відповідного виду діяльності (О. Дорошенко, Н. Бєлікова, С. Гаркуша) та впровадження здоров'язберігальних технологій в освітній процес (М. Смирнов, М. Носко, С. Гаркуша, О. Воєділова, А. Фастівець, С. Луканьова, М. Лютик).

Проблеми впровадження інформаційно-комунікаційних технологій у навчальний процес досліджували В. Биков, Г. Бордовський, Ю. Брановський, Я. Ваграменко, Ю. Горошко, В. Делінгер, Т. Добутько, М. Жалдак, Г. Жабєєв, І. Ізвозчикова, Г. Козлакова, А. Кузнецова, В. Клочко, В. Лаптєва, В. Матросова, Н. Морзе, Т. Олійник, М. Пригодій, С. Раков, С. Смирнов, О. Торубара, А. Кудін та інші. У дослідженні проблем інформатизації освіти провідну роль відіграють роботи В. Беспалька, П. Гальперіна, Т. Ільїної, Ю. Машбиця, В. Монахова й інших, присвячені питанням психологопедагогічних основ ефективного використання комп'ютерів у навчально-виховному процесі, дидактичних можливостей комп'ютерної техніки та її програмного забезпечення.

Виділення не вирішених раніше частин загальної проблеми. Інформатизація профресійної освіти характеризується вдосконаленням і розповсюдженням нових інформаційних технологій, серед них й інтерактивних, які широко використовуються в процесі взаємодії викладача і студента в сучасному освітньому процесі 3ВО галузі фрізичної культури і спорту (далі - ФКіС). У зв'язку з цим майбутній фрахівець ФКіС повинен не тільки мати достатні знання у сорері інформаційних технологій, а й бути достатньо кваліфікованим для їх застосування в профресіональній діяльності. Досягненню такої мети має сприяти підготовка майбутніх фахівців ФКіС у сфері інформатизації освіти. Тому професійна підготовка майбутніх фрахівців ФКіС сьогодні має передбачати фрормування та розвиток їхньої інформаційно-цифррової культури.

Мета статті - розглянути теоретичні та практичні засади фрормування й розвитку інфрормаційно-цифррової культури майбутніх фахівців ФКіС.

Виклад основного матеріалу. Проблематика формування інфрормаційно-цифрової культури (або ії основ) досліджується 3 погляду підвищення загальноосвітнього рівня особистості або як окремий аспект професійних знань і навичок фрахівця. Ці питання розглядаються в дисертаційних дослідженнях, зокрема в роботах М. Близнюк [1], С. Гунько [2], О. Ільків [3]. До необхідної теоретичної бази належать знання про інфрормацію, інсрормаційні процеси та інформаційні системи, загальні принципи розв'язання задач за допомогою комп'ютера, загальне уявлення про архітектуру та фрункціонування комп'ютера, про можливості використання глобальної мережі Інтернет. Практичні навички використання засобів сучасних IKT передбачають уміння працювати з прикладними програмними засобами загального призначення: операційними системами, програмами-архіваторами, антивірусними програмами, редакторами текстів, графічними редакторами, електронними таблицями, зазвичай це використання пакету програм MSOffice (a саме MS Word, MS Excel, MS Access, інших програм пакету).

В основу процесу фрормування інфрормаційноцифрової культури майбутніх фрахівців ФКіС в умовах змішаного навчання ми поклали методологічні підходи (системний, цілісний, особистісно-орієнтований, діяльнісний, полісуб'єктний, технологічний, інтегративний, BYOD-підхід, візуально-цифровий, культурологічний, студентоцентрований підходи) та принципи: загальнодидактичні; просресійного навчання; використання змішаного освітнього середовища, створення цифрових освітніх ресурсів.

Теоретичний концепт визначає систему ідей, вихідних категорій, основних понять, без яких ускладнене розуміння сутності проблеми, що досліджується, і містить такі положення:

- реномен інфрормаційно-цифрової культури $є$ утворенням, що має складну структуру й має формуватися через свої складники;

- організація змішаного освітнього середовища (3ОС) ЗВО вимагає органічного поєднання традиційних і дистанційних технологій, інтеграції спеціалізованих ПЗ та інформаційно-ресурсного забезпечення освітнього процесу;

- фрормування інформаційно-цифррової культури майбутніх фрахівців ФКіС в умовах змішаного навчання $€$ компонентом їхньої професійної підготовки та реалізується як педагогічна система, що складається із взаємопов'язаних підсистем;

- необхідними умовами формування інформаційно-цифрової культури майбутніх фрахівців ФКіС є: 1) комплексне проектування змішаного освітнього середовища ЗВО, діджиталізація професійної підготовки, посилення міжпредметних зв'язків між фраховими та інформатичними дисциплінами; 2) організація квазіпрофеесійної діяльності майбутніх фрахівців ФКіС у напрямі розвитку вмінь використовувати IT профеесійної спрямованості; 3) цілеспрямована мотивація до підвищення рівня власної ІЦК (розгляд історичних аспектів розвитку галузі ФКіС, зміцнення гуманістичних цінностей фізичного виховання, утворення ціннісних установок на застосування IT для фрізкультурнооздоровчої діяльності); 4) оптимізація комунікації між учасниками освітнього процесу, забезпечення спілкування зі стейкхолдерами та подолання пси- 
хоемоційних бар'єрів до роботи 3 IT освітнього призначення;

Практичний концепт описує систему дій, які забезпечують практичне розв'язання поставленої проблеми, і характеризується такими положеннями - формування інформаційно-цифрової культури майбутніх фрахівців ФКіС в умовах змішаного навчання:

- відбувається через педагогічну систему, реалізація якої спирається на змішане освітнє середовище 3ВО;

- вимагає врахування розвитку цифррових технологій у галузі здоров'я, обізнаності майбутніх фрахівців ФКіС у сфері IT, здатність до самоосвіти;

- потребує фрормування навичок критичного аналізу, оцінювання, порівняння, узагальнення;

- потребує розвитку розумової працездатності, інтелектуальних здібностей, оптимізації комунікації між викладачем і студентами, подолання психоемоційних бар'єрів до роботи 3 IT освітнього призначення.

Відповідно, процес фрормування інформаційноцифрової культури майбутніх фрахівців ФКіС в умовах змішаного навчання передбачає вдосконалення змісту (модернізація курсів інфрорматичних дисциплін; модернізація курсу іноземної мови за профресійним спрямуванням; розробка й модернізація дистанційних курсів до фрахових дисциплін, до вибіркових дисциплін; створення вокабуляріїв і тезаурусів до фрахових курсів для оптимізації комунікації між викладачем і студентами, подолання психоемоційних бар'єрів; розробка й упровадження спецкурсів «Розвиток інтелектуальних здібностей», «ІТ у фрізкультурно-оздоровчій діяльності»; використання можливостей неформальної освіти та самоосвіти), методів (проектні технології; методи впливу на особистість (заохочення, вимога, переконання); інтерактивні технології; проблемне навчання) і засобів (EOP; 30С 3BO); технічні ресурси; Інтернет-ресурси; комунікаційні програми (Viber, Messenger, Telegram тощо); системи управління навчанням (Moodle); відкриті освітні ресурси; технології доповненої реальності; технології цифрового здоров'я; навчання та форми (лекції-візуалізації; відеоконференції; чати; вебінари; тренінги; майстер-класи; дискусії; семінари; лабораторні роботи; курсові проекти; самостійна робота; неформальна освіта (науково-практичні конференції для студентської молоді, студентські олімпіади та інтелектуальні конкурси)) навчальної діяльності студентів.

Сорормульована мета передбачає фрормування компонент інформаційно-цифрової культури майбутніх фрахівців ФКіС в умовах змішаного навчання:

1) аксіологічний - світоглядне бачення інформаційно-цифрових технологій в інформаційному суспільстві, розуміння та усвідомлення ролі й значення IT в професійній діяльності;
2) мотиваційний - мотивація використовувати IT професійної спрямованості, до підвищення рівня власної ІЦК;

3) технологічний - володіння різноманітним комп'ютерним обладнанням і програмним забезпеченням, мережевими технологіями, технологіями мультимедіа, презентаційними технологіями тощо, здатність використовувати IKT для проектування профресійної діяльності, реалізації особистісно-орієнтованого процесу навчання, конструювання навчально-тренувальних занять тощо;

4) інфрормаційний - фрахові знання та навички роботи 3 інорормацією: пошук, управління, оцінювання, створення інфрормації, передача тощо, уміння конструювати цифрові освітні ресурси;

5) комунікативний - мовно-мовленнєва підготовка майбутніх фрахівців ФКіС, зокрема, з англійської мови;

6) сугестивний - володіння засобами вербального й невербального емоційно забарвленого впливу за допомогою вербальних каналів з метою трансляції потрібної професійної інфрормації;

7) рефлексивний - здатність до вдосконалення та розвитку у сфрері цифрових технологій для професійної діяльності й особистого розвитку.

Формування інформаційно-цифрової культури майбутніх фрахівців ФКіС в умовах змішаного навчання включає діагностику результатів профресійної підготовки, яка базується на критеріях і показниках сорормованості складників інформаційно-цифрової культури майбутніх фрахівців ФКіС: ціннісному (показник - ІТ-освіченість), поведінковому (показник - мотивація), процедурному (показники - навички володіння комп'ютерним обладнанням; навички володіння програмним забезпеченням; здатність використовувати IT у сорері ФКіС), когнітивному (показники - інорорматична обізнаність, уміння конструювати EOP), мовно-мовленнєвому (показники - лексична обізнаність, уміння е-комунікації), психологічному (показники - розумова продуктивність, емоційний інтелект), особистісному (показники - здатність до самоосвіти, рефрлексія) критеріях.

За аналізом різних підходів до визначення рівня навчальних досягнень нами виділено такі три рівні сорормованості складників інфрормаційно-цифрової культури майбутніх фрахівців ФКіС: початкового; середньому; високому.

Результатом реалізації процесу фрормування інфрормаційно-цифрової культури майбутніх фрахівців ФКіС в умовах змішаного навчання $€$ позитивна динаміка в рівнях сорормованості складників інфрормаційно-цифрової культури майбутніх фахівців ФКіС.

Висновки. Теоретичний аналіз досліджень та узагальнення практичного досвіду вказують на те, що підвищення якості підготовки фрахівців ФКіС потребує особливої уваги саме до оптимізації 
освітнього процесу у ЗВО. Зростання ролі фрізичної культури і спорту, конкретизація завдань, що стоять перед фрізкультурним рухом, наполегливо вимагають удосконалення організаційної структури управління розвитком фрізичного виховання на основі інноваційного підходу та цілеспрямованого використання законів соціального й економічного розвитку інформативного суспільства, специфрічних закономірностей фрізичної культури, а також закономірностей і принципів навчання та виховання. Отже, у процесі фрормування інфрормаційно-цифрової культури майбутніх фрахівців ФКіС у процесі їхньої професійної підготовки варто активно використовувати IT, що серед іншого передбачає розробку та використання освітніх ресурсів (навчальних курсів 3 відповідним навчально-методичним супроводом), дає можливість студентам відчути себе суб'єктом освіт- нього процесу, побачити переваги використання IT у професійній діяльності й визначити власні шляхи саморозвитку в професійному напрямі.

\section{БІБЛОГРАФІЧНИЙ СПИСОК:}

1. Близнюк М.М. Формування основ інформаційної культури у студентів вищих навчальних закладів прикладного та декоративного мистецтва : дис. ... канд. пед. наук : 13.00.02 / Прикарпатський ун-т ім. Василя Стефаника. Івано-Франківськ, 2000. 208 с.

2. Гунько С.О. Формування системи знань про інформаційні технології у майбутніх вчителів початкових класів : дис. ... канд. пед. наук : 13.00.01 / Волинський держ. ун-т ім. Лесі Українки. Луцьк, 1998. 175 с.

3. Ільків О.С. Формування інфрормаційної культури студентів аграрних закладів освіти I-II рівнів акредитації : дис. ... канд. пед. наук : 13.00.04 / Міжнародний ун-т «Рівненський економіко-гуманітарний ін-т» ім. Степана Дем'янчука. Рівне, 2003. 239 с. 